\title{
SINTESIS POLI (GLIKOLIDA-CO-LAKTIDA) DAN UJI BIODEGRADABILITASNYA
}

\section{SYNTHESIS OF POLY(GLYCOLIDE-CO-LACTIDE) AND THEIR BIODEGRADABILITY ASSAY}

\author{
Rofiq Sunaryanto ${ }^{1}$ dan Hardaning Pranamuda ${ }^{2}$ \\ ${ }^{1}$ Balai Pengkajian Bioteknologi BPP Teknologi \\ Kawasan PUSPIPTEK Serpong Tangerang Banten 15314. \\ ${ }^{2}$ Pusat Teknologi Bioindustri BPP Teknologi \\ Kawasan PUSPIPTEK Serpong Tangerang Banten 15314 \\ E-mail : rofiqsn@yahoo.com
}

Diterima : 03 Agustus 2015, Revisi : 29 Agustus 2015, Disetujui : 21 September 2015

\begin{abstract}
ABSTRAK
Poliglikolida dan polilaktida merupakan poliester alifatik yang mengandung pengulangan unit (monomer) dari glikolida dan laktida. Polimer ini dipandang sebagai green polymer yang dapat dihasilkan dari sumber pertanian. Pengembangan biodegradable plastik yang berbasiskan bahan baku alam masih penting untuk dilakukan. Poli (glikolidaco-laktida) merupakan hasil polimerisasi dari campuran monomer glikolida dengan laktida. Kopolimerisasi glikolida dengan beberapa turunan laktida seperti D-laktida, L-laktida, dan DL-laktida menggunakan katalis $\mathrm{Sn}(\mathrm{Oct})_{2}$ telah dilakukan. Polimerisasi dilakukan dengan metode pembukaan cincin glikolida dan laktida tanpa menggunakan pelarut sebagai media reaksi. Polimerasasi dilakukan secara pelelehan pada suhu $130{ }^{\circ} \mathrm{C}$ selama 36 jam. Dari hasil penelitian ini diperoleh informasi sebagai berikut; polimerisasi glikolida dengan D-laktida menghasilkan polimer dengan bobot molekul ratarata $8,2 \times 10^{3}$ dan rendemen sebesar $72 \%$. Polimerisasi glikolida dengan L-laktida menghasilkan bobot molekul rata-rata $2,8 \times 10^{3}$ dan rendemen sebesar $36 \%$. Polimerisasi glikolida dengan DL-laktida menghasilkan bobot molekul rata-rata $2,5 \times 10^{3}$ dengan rendemen sebesar $48 \%$. Hasil uji penguburan (burial test) selama 28 hari menunjukkan poli (glikolida-co-Llaktida) terdegradasi paling cepat dibandingkan polimer lain, yaitu terdegradasi sebesar $32 \%$. Sedangkan poli (glikolida-co-DL-laktida) dan poli (glikolida-co-Dlaktida) menunjukkan degradasi yang hampir sama yaitu sebesar 20\%. Dibandingkan dengan PHB (polihidroksibutirat), poli (glikolida-co-laktida) terdegradasi lebih lambat.
\end{abstract}

Kata kunci: Glikolida, laktida, kopolimerisasi, plastik biodegradable

\section{ABSTRACT}

Polylactide and polyglycolide are important aliphatic polyester consist of lactide and glycolide repeats unit. It is considered as green polymer due to it is produced from renewable agricultural resources. The development of biodegradable plastics based on agricultural resources is still important to be done. Copolymerization of glycolide with D-lactide, L-lactide, and DL-lactide using a $\mathrm{Sn}(\mathrm{Oct})_{2}$ as catalyst had been carried out. Polymerization was conducted by ring-opening of lactide and glycolide without the solvents but melting polymerization. Polymerization were conducted at $130{ }^{\circ} \mathrm{C}$ for 130 hours. Result of this study showed that polymerization of glycolide with D-lactide produce polymers with an average molecular weight of $8.2 \times 10^{3}$ and a yield of $72 \%$. Polymerization of glycolide with L-lactide produce polymer with an average molecular weight of $2.8 \times 10^{3}$ and a yield of $36 \%$. Polymerization glycolide with DL-lactide produce polymer with an average molecular weight of $2.5 \times 10^{3}$ with a $48 \%$ yield. The burial test for 28 days showed poly (glycolide-co-Llaktida) degraded faster than other polymers, namely degraded $32 \%$. While poly (glycolide-co-DL-lactide) and poly (glycolide-co-Dlactide) showed similar degradation that is equal to $20 \%$. Compared with PHB (polyhydroxybutyrate), poly (glycolide-co-lactide) degraded more slowly.

Keywords: Glycolide, lactide, copolymerization, biodegradable plastic

\section{PENDAHULUAN}

Saat ini perkembangan teknologi plastik biodegradable meningkat tajam. 
Telah banyak hasil-hasil penelitian mengenai plastik biodegradable yang diproduksi skala industri. Namun demikian apabila dibandingkan dengan volume produksi plastik turunan minyak bumi (plastik konvensional) masih jauh lebih kecil. Hal ini disebabkan mahalnya bahan baku serta proses produksinya. Produk plastik biodegradable yang beredar dipasaran saat ini banyak digunakan dalam bidang kedokteran. Kebutuhan pasar dunia terhadap plastik biodegradable terus meningkat. Tercatat pada tahun 2010 kebutuhan pasar dunia akan plastik biodegradable mencapai 664.000 ton dan diperkirakan pada tahun 2016 mencapai 2.330.000 ton $^{(1)}$. Kecenderungan kenaikan permintaan pasar dunia plastik biodegradable disebabkan oleh beberapa karakteristik yang cocok untuk aplikasi kedokteran seperti keras, tidak beracun, tidak bersifat karsinogenik, biokompatibel, ramah terhadap lingkungan, tidak mudah bereaksi dengan darah, tulang, jaringan, dan cairan tubuh.

Jenis plastik biodegradable yang sekarang ini banyak beredar di pasaran antara lain poliasamlaktat atau polilaktida, poli $\quad(\beta$-hidroksibutirat), polibutilena suksinat, polikaprolakton, dan poliglikolida. Poliasamlaktat atau polilaktida dikenal memiliki sifat fisik yang unggul seperti transparan, titik leleh yang tinggi, uji tarik yang tinggi serta mudah terdegradasi khususnya enzim golongan protease dan lipase $^{(2)}$, disamping itu polilaktida juga mudah didegradasi dalam larutan alkali ${ }^{(3)}$. Bahan baku poliasamlaktat adalah asam laktat yang dapat diproduksi melalui fermentasi karbohidrat seperti jagung, tapioka, sagu. Produk plastik biodegradable dari poliasam laktat (PLA) sudah banyak diaplikasikan sebagai plastik biomedik. Polilaktida merupakan ester rantai tertutup dari asam laktat (asam 2dihidroksipropanoat). Dengan pemanasan dan penambahan asam dalam asam laktat maka akan terbentuk rantai tertutup laktida ${ }^{(4)}$. Laktida mempunyai 2 atom kiral sehingga laktida dapat membentuk tiga macam stereoisomer, yaitu D-laktida, Llaktida, dan DL-laktida.

Jenis plastik biodegradabel yang tidak kalah penting dalam aplikasi dibidang kedokteran adalah poliglikolida. Poliglikolida dapat dibuat langsung dari polimerisasi asam glikolida ${ }^{(5)}$. Dari penelitian yang telah dilakukan polimerisasi asam glikolida menggunakan katalis trifilic acid. Polimerisasi asam glikolida ini menghasilkan poliglikolida dengan rendemen mencapai $92 \%$. Sudah banyak plastik biodegradable turunan glikolida yang digunakan sebagai bahan peralatan kedokteran maupun bahan pembawa (carrier) obat. Penelitian yang telah dilakukan oleh $\mathrm{Xu}$ et $a l^{(6)}$ poliglikolida dapat digunakan sebagai bahan pembawa (carrier) isoniazid (INH) dan rifampin (RIF) sebagai obat TBC. Dengan poliglikolida, isonizid dapat dilepaskan (control release) selama 3-6 minggu. Menurut Smith et $a l^{(7)}$ kopolimerisasi glikolida dengan laktida dapat digunakan sebagai bahan pembawa bischloroethynitrosourea (BCNU) untuk pengobatan glioblastoma. Kopolimerisasi glikolida dengan kaprolakton dapat digunakan sebagai bahan penyangga jaringan otot ${ }^{(8)}$.

Selain aplikasi dibidang kedokteran, poliglikolida juga banyak diaplikasikan dalam bidang elektronika, yaitu sebagai insulator mekanik, termal insulator, solid support katalis ${ }^{(9,10)}$. Menurut Bencherif et $a l^{(11)}$ poliglikolida dapat dibuat sebagai bahan polimeric foam atau macroporous polimeric. Polimer ini memiliki porositas mencapai $87 \%$ dengan luas area $20 \mathrm{~m}^{2} / \mathrm{g}$ dan densitasnya $120 \mathrm{mg} / \mathrm{cc}$.

Penelitian ini bertujuan untuk mendapatkan polimer hasil dari kopolimerisasi glikolida dengan D-laktida, L-laktida dan DL-laktida, serta mendapatkan informasi degradasi polimer hasil uji penguburan dalam tanah. 


\section{BAHAN DAN METODA}

\section{Bahan dan peralatan}

Bahan yang digunakan dalam polimrisasi antara lain: L-laktida (purac chemical), D-laktida (purac chemical), DLlaktida (purac chemical), glikolida (purac chemical), kloroform (wako chemical), nheksana (wako chemical), gas nitrogen, $\mathrm{Sn}(\mathrm{Oct})_{2}$. Selanjutnya peralatan yang digunakan meliputi; peralatan gelas kimia, labu takar $100 \mathrm{~mL}$ yang yang dilengkapi kran pembuk/penutup, evaporator buchi, vakum oven, FTIR 8100, GPC (TOSOH), $\mathrm{H}^{1}$ NMR JEOL JNM-EX 270, DSC Seiko Scientific Instruments.

\section{Polimerisasi glikolida dengan laktida.}

Metode polimerisasi dilakukan dengan mengacu dari penelitian Purnama et al. (2012) yang dimodifikasi ${ }^{(12)}$. Polimerisasi dilakukan di dalam labu takar $100 \mathrm{~mL}$. Sebanyak 0,5 gram glikolida dan 0,5 gram laktida (D-laktida, L-laktida, atau DL-laktida) dan $1 \%$ katalis $\mathrm{Sn}(\mathrm{Oct})_{2}$ dimasukkan dalam labu takar. Selanjutnya labu takar divakum untuk membuang udara yang berada dalam labu takar dan diisi dengan gas nitrogen. Kemudian diinkubasi dalam suhu $130^{\circ} \mathrm{C}$ selama 36 jam. Setelah reaksi selesai padatan polimer yang terbentuk dilarutkan dalam kloroform dan disaring dengan kertas saring. Filtrat diuapkan dengan rotavapor pada suhu 65 ${ }^{\circ} \mathrm{C}$ dalam kondisi vakum sampai terbentuk cairan kental atau gel. Selanjutnya dilakukan kristalisasi dengan meneteskan gel polimer ke dalam heksana $200 \mathrm{~mL}$. Polimer yang terbentuk akan mengendap, sedangkan sisa monomer akan larut ke dalam pelarut heksana. Endapan polimer disaring dan dikeringkan dalam suhu kamar selama 24 jam. Padatan polimer ditimbang dan dikarakterisasi. Karakterisasi meliputi penentuan struktur molekul menggunakan $\mathrm{H}^{1}$ NMR (Nuclear magnetic resonance) JNM-EX 270 FT-NMR spectrometer (JEOL, Japan) dan FTIR 8100 (Fourier Transform Infrared Spectroscopy), bobot molekul ditentukan menggunakan GPC (Gel Permeation Chromatography) HLC8020 GPC system (Tosoh Co., Japan), dan titik leleh ditentukan menggunakan DSC (Differential Scanning Calorimetry) Seiko Scientific Instruments.

\section{Uji degradasi biodegradable plastik.}

Uji degradasi plastik dilakukan dengan metode penguburan. Polimer plastik hasil sintesis yang telah dibentuk lembaran tipis dikubur dalam tanah. Selang interval 7 hari dilakukan pengambilan sampel sampai dengan 28 hari. Selanjutnya dibuat kurva degradasi (\%) versus lama penguburan (hari). Sebagai kontrol digunakan PHB (polihidroksibutirat) yang dikenal sebagai plastik yang paling mudah didegradasi oleh mikroba.

\section{HASIL DAN PEMBAHASAN}

Data hasil pengamatan kopolimerisasi glikolida dengan laktida disajikan pada Tabel 1.

Tabel 1. Hasil kopolimerisasi glikolida-laktida dengan katalis $\mathrm{Sn}(\mathrm{Oct})_{2}$.

\begin{tabular}{cccccc}
\hline No & Jenis Polimer & Bentuk/warna & $\begin{array}{c}\text { Rendemen } \\
(\boldsymbol{\%})\end{array}$ & Mn & $\begin{array}{c}\text { Titik Leleh } \\
\left({ }^{\circ} \mathbf{C}\right)\end{array}$ \\
\hline 1 & Glikolida-co-L laktida & Padatan putih & 36 & $2,8 \times 10^{3}$ & t.d \\
2 & Glikolidaco- D-laktida & Padatan putih & 72 & $8,2 \times 10^{3}$ & t.d \\
3 & Glikolida-co-DL-laktida & Padatan putih & 48 & $2,5 \times 10^{3}$ & t.d \\
\hline Keterangan $:$ tdd
\end{tabular}

Keterangan $:$ t.d. $=$ tidak terdeteksi 
Tabel 1. terlihat bahwa kopolimerisasi glikolida dengan beberapa stereoisomer laktida menghasilkan rendemen dan bobot molekul rata-rata $(\mathrm{Mn})$ yang berbeda beda. Data tersebut memberikan informasi bahwa efek stereoisomer laktida juga berpengaruh terhadap pembentukan rantai polimer tersebut. Hal yang sama terjadi pada polimerisasi D-laktida, L-laktida, dan DLlaktida yang dilaporkan oleh Lopes et $a l .{ }^{(13)}$. Polimerisasi D, L, dan DL laktida menghasilkan rendemen dan bobot molekul rata-rata yang berbeda walaupun struktur dan bobot molekul monomer serta kondisi reaksinya sama. Ditinjau dari titik leleh dari ketiga polimer tersebut ternyata ketiga polimer tersebut tidak dapat terdeteksi titik lelehnya, hal ini disebabkan karena kopolimerisasi polilglikolida-laktida bersifat amorf. Hal yang sama dilaporkan oleh Erbetta et $a l^{(14)}$ walaupun glikolida dan laktida memiliki titik leleh pada titik tertentu namun demikian polimerisasi dari kedua monomer tersebut menghasilkan jenis polimer yang bersifat amorf dan tidak dapat ditentukan titik lelehnya.

Untuk memperkirakan struktur molekul hasil kopolimerisasi poli (glikolida-laktida) maka polimer dianalisis menggunakan ${ }^{1} \mathrm{H}$ NMR dan FTIR. Dari hasil analisis ternyata ketiga jenis kopolimer tersebut memiliki spektrum $\mathrm{H}^{1}$ NMR dan FTIR yang sama. Hal ini disebabkan oleh rantai polimer yang dibentuk oleh ketiga polimer tersebut adalah sama, yang membedakan adalah panjang rantai yang terbentuk dan geometri (stereokimia) polimer. Dengan demikian spektrum $\mathrm{H}^{1}$ NMR satu dimensi ini belum dapat membedakan stereokimia gugus molekul seperti D-laktida, L-laktida, dan DL-laktida. Adapun data $\mathrm{H}^{1}$ NMR dan FTIR Poli(glikolida-co-Llaktida) disajikan dalam Gambar 1 dan Gambar 2. Spektogram proton NMR (270 MHZ:
$\left.\mathrm{CDCL}_{3}\right) \delta: 1,599$ duplet (a) adalah proton dari $\left(\mathrm{CH}_{3}\right)$ laktida, $\delta$ : 4,82 singlet (b) adalah proton dari $\left(\mathrm{CH}_{2}\right)$ glikolida, dan $\delta$ : 5,15 kuartet (c) adalah proton dari $(\mathrm{CH})$ laktida. Pita yang tampak pada $\delta 1,270$ dan $\delta 0,883$ adalah pita yang ditimbulkan dari pelarut heksana yang digunakan sebagai pelarut saat proses kristalisasi polimer.

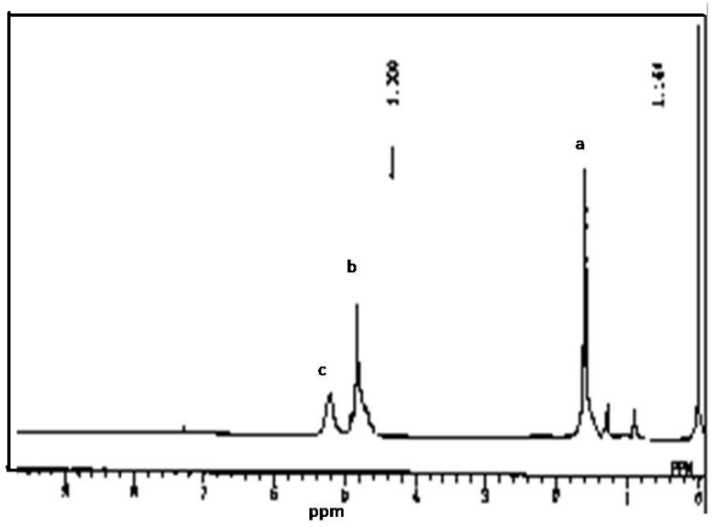

Gambar 1. Spektogram $\mathrm{H}^{1} \mathrm{NMR}$ poli(glikolida-co-Llaktida)

Spektogram $\mathrm{H}^{1}$ NMR poli(glikolidaco-laktida) yang sama ditunjukkan oleh Erbetta et al. (2012) $)^{(14)}$, dimana gugus fungsional $\mathrm{CH}_{3}$ dari laktida ditunjukkan dalam pita pergeseran kimia pada rentang $\delta$ : 1,490-1,687, dan gugus funsional $\mathrm{CH}_{2}$ dari glikolida ditunjukkan pada pergeseran kimia pada rentang $\delta$ : 4,675-4,909, dan gugus fungsional $\mathrm{CH}$ dari laktida ditunjukkan pada pergeseran kimia pada renang $\delta: 5,157-5,302$. Selanjutnya hasil uji menggunakan FTIR disajikan dalam Gambar 2.

Gambar 2. menunjukkan spektogram FTIR hasil kopolimerisasi glikolida-laktida. Serapan kuat pada $1750 \mathrm{~cm}^{-1}$ menunjukkan gugus karbonil. Serapan kuat pada 1100 $\mathrm{cm}^{-1}$ menunjukkan adanya gugus ester (CO). Pita serapan rentang 3000-2800 $\mathrm{cm}^{-1}$ dan pita $1450 \mathrm{~cm}^{-1}$ menunjukkan gugus alkil sedangkan pita pada 1370 menunjukkan adanya gugus metil $\left(\mathrm{CH}_{3}\right)$. 


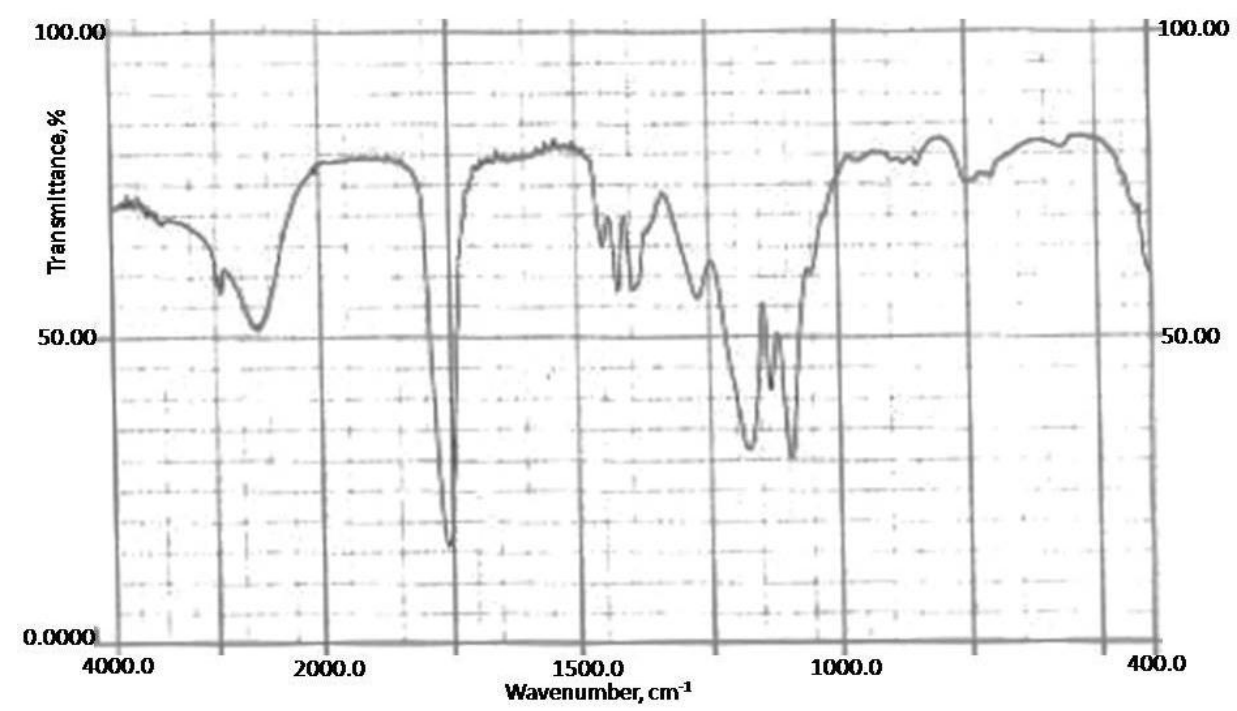

Gambar 2. Spektogram FTIR poli (glikolida-co-Llaktida)

Pita kecil sekitar $750 \quad \mathrm{~cm}^{-1}$ menunjukkan gugus metilen $\left(\mathrm{CH}_{2}\right)$. Pita stretching akibat vibrasi gugus $\mathrm{C}-\mathrm{C}(=\mathrm{O})-\mathrm{O}$ ditunjukkan pada serapan pita pada 1300 dan 1150. Spektogram FTIR mampu menunjukkan gugus-gugus $\mathrm{C}=\mathrm{O}, \mathrm{C}-\mathrm{O}, \mathrm{CH}_{3}$, $\mathrm{CH}_{2}$ dan $\mathrm{CH}$. Profil spektrogram FTIR yang dihasilkan oleh poli(glikolida-co-Llaktida) hasil percobaan ini sangat mirip dengan profil spektogram FTIR referensi dari kajian literatur ${ }^{14}$.

Analisis berdasarkan spektogram $\mathrm{H}^{1} \mathrm{NMR}$ dan FTIR, reaksi yang terjadi dari kedua monomer tersebut adalah seperti pada Gambar 3.

Reaksi polimerisasi ini dikategorikan sebagai polimerisasi pembukaan cincin atau disebut Ring Opening Polymerization (ROP). Reaksi diinisiasi dengan pembukaan cincin masing-masing monomer laktida dan glikolida karena adanya serangan dari nukleufilik gugus logam Sn. Katalis $\mathrm{Sn}(\mathrm{Oct})_{2}$ akan menyerang gugus karbonil monomer laktida dan glikolida dan terjadi pembelahan ikatan rangkap pada gugus karbonil sehingga terjadi pembukaan cincin $^{(15)}$.

Selanjutnya untuk mengetahui tingkat degradasi plastik poli(glikolida-colaktida) maka dilakukan uji penguburan (burial test) menggunakan kontrol pembanding plastik PHB (polihidroksibutirat). Hasil pengamatan uji penguburan disajikan dalam Gambar 4.

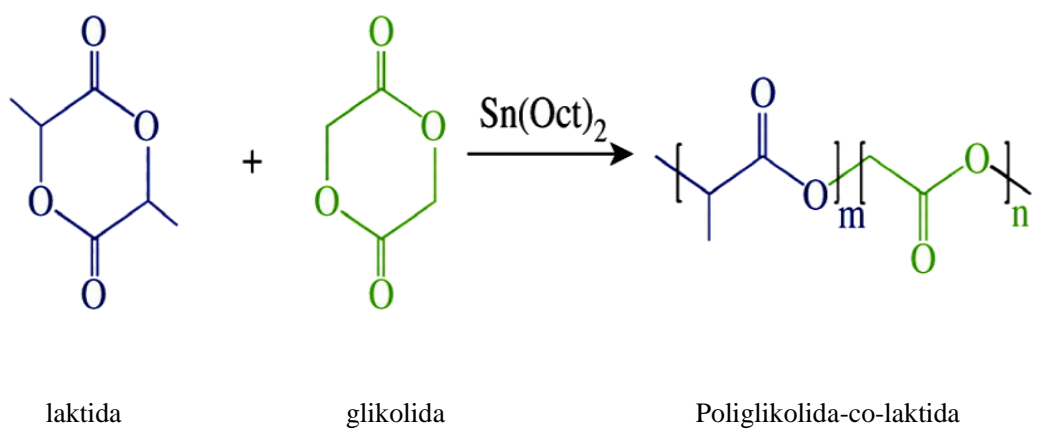

Gambar 3. Reaksi laktida dengan glikoda 


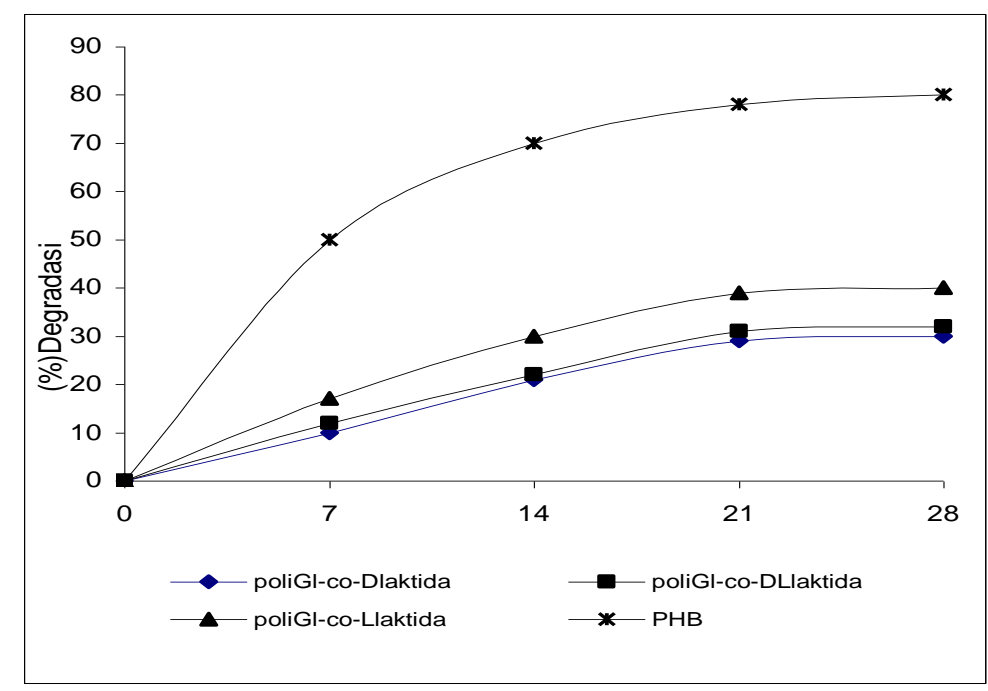

Gambar 4. Degradasi poli(glikolida-co-laktida) setelah penguburan selama 28 hari

Gambar 4 menunjukkan bahwa poli (glikolida-co-laktida) terdegradasi jauh lebih lambat dibandingkan dengan PHB. Polihidroksibutirat dikenal sebagai plastik yang mudah didegradasi oleh mikroorganisme. Plastik tersebut dapat diproduksi melalui fermentasi atau lebih dikenal sebagai bioplastik.

Dari ketiga jenis kopolimer glikolidalaktida menunjukkan poli (glikolida-coLlaktida) memiliki tingkat degradasi yang lebih cepat (32\% degradasi) dibandingkan polimer poli(glikolida-co-Dlaktida) dan poli (glikolida-co-DLlaktida). Sedangkan polimer poli (glikolida-co-Dlaktida) dan poli (glikolida-co-DLlaktida) menunjukkan pola kemiripan degradasi saat uji penguburan yaitu terjadi degradasi sebesar $20 \%$ pada hari ke-28. Hal ini menunjukkan bahwa efek stereoisomer dari monomer poli(glikolida-co-laktida) berpengaruh terhadap kecepatan degradasi plastik oleh mikroorganisme tanah. Hal yang sama dilaporkan Chuensangjun et al. ${ }^{(16)}$ stereoisomer polilaktida berpengaruh terhadap kecepatan degradasi polilaktida oleh mikroorganisme. Menurut Cai et $a l^{(17)}$ mekanisme degradasi polimer plastik polilaktida merupakan degradasi karena aktivitas enzim yang dihasilkan oleh mikroorganisme. Dengan demikian kecepatan hidrolisis polilaktida sebagai substrat tergantung dari kecepatan reaksi enzim terhadap substrat. Stereokimia molekul substrat sangat berpengaruh terhadap kecepatan reaksi enzim. Seperti diketahui substrat setiap enzim adalah spesifik, baik dari gugus fungsional molekul substrat, besarnya molekul substrat maupun stereokimia molekul substrat. Menurut Renee et $a l^{(18)}$ stereo kimia polimer, sifat kristal dan amorf polilaktida berpengaruh terhadap kecepatan degradasi polilaktida. Namun demikian posisi rantai ikatan polilaktida atau gugus fungsional yang berbengaruh terhadap kecepatan degradasi oleh mikroorganisme sampai saat ini belum dapat dijelaskan.

\section{KESIMPULAN}

Dari hasil percobaan yang telah dilakukan dapat disimpulkan bahwa polimerisasi glikolida dengan D-laktida menggunakan katalis $\mathrm{Sn}(\mathrm{Oct})_{2}$ menghasilkan polimer dengan bobot molekul rata-rata $8,2 \times 10^{3}$ dengan rendemen $72 \%$, sedangkan polimerisasi glikolida dengan L-laktida menghasilkan bobot molekul rata-rata $2,8 \times 10^{3}$ dengan rendemen $36 \%$. Polimerisasi DL-laktida dengan 
glikolida menghasilkan bobot molekul ratarata $2,5 \times 10^{3}$ dengan rendemen $48 \%$. Hasil uji penguburan menunjukkan poli (glikolida-co-Llaktida) paling mudah terdegradasi dibandingkan kedua polimer tersebut. Pada hari ke-28 tingkat degradasi poli (glikolida-co-L-laktida) sebesar $32 \%$, degradasi poli (glikolida-co-Dlaktida) dan poli (glikolida-co-DL-laktida) sebesar 20 $\%$.

\section{DAFTAR PUSTAKA}

1. Plastemart - Plastic Technical Article. Situs resmi. Tersedia dalam: http://www.plastemart.com/PlasticTechnical-Article.asp [diunduh pada tanggal 26 April 2015].

2. L.C. Cheolho, S. Hong. An overview of the synthesis and synthetic mechanism of poly(lactic acid). Mod.Chem.Appl. 2(4) 1-5 (2014).

3. L.Xu, K. Crawford, C.B. Gorman. Effects of temperature and $\mathrm{pH}$ on the degradation of poly(lactic acid) brushes. Macromolecules. 4(12) 4777-82 (2011).

4. H. Pudjatmaka. Kimia Organik jilid 1, (ed 2). Erlangga Press Jakarta,1984

5. E. Gokturk, A.G. Pemba, S.A. Miller. Polyglycolic from the direct polymerization of renewable $\mathrm{c} 1$ feedstocks. Polym Chem.6 3918-25 (2015).

6. S.W. Xu, X.Wei, K.Wei, X.Cao, S.Zhong. A mesoporous silicon/poly(DL-lactic-co-glycolic) acid microsphere for long time antituberculosis drug delivery. Int.J. Pharm. 476(1) 116-23 (2014).

7. S.J. Smith, C.V. Rahman, P.A. Clarke, A.A. Ritchie, T.W. Gould, J.H. Ward, K.M. Shakesheff, R.G. Grundy, R. Rahman. Surgical delivery of drug releasing poly (lactic-co-glycolic acid)/poly(ethylene glycol) paste with in vivo effects against glioblastoma. Ann. R. Coll. Surg. Engl. 96(7) 495-501 (2014).

8. P. Gentile, V. Chiono, I.Carmagnola, P.V. Hatton. An Overview of poly(lactic-co-glycolic) acid (PLGA)based biomaterials for bone tissue engineering. Int. J. Mol. Sci.15 3640-59 (2014).

9. V. Singh dan M. Tiwari. Structureprocessing-property relationship of poly(glycolic acid) for drug delivery systems 1: Synthesis and catalysis. Inter J Polymer Sci.1-23 (2010).

10. N. Michael. Biopolymers: applications and trends. Elsevier Inc. Oxford UK, 2015

11. S.A. Bencherif, T.M. Braschler, P. Renaud. Advances in the design of macroporous polymer scaffolds for potential applications in dentistry. $J$. Periodontal.Implant. Sci. 43(6) 251-61 (2013).

12. P. Purnama, Y. Jung, C.H. Hong, D.S.Han, S.H.Kim. Synthesis of poly(D-lactide) with different molecular weigh via melt-polymerization. Macromolecular Res 20(5):515-19 (2012).

13. M.S. Lopes, A.L. Jardini, R.M. Filho. Synthesis and characterizations of poly (lactic acid) by ring-opening polymerization for biomedical applications. Chem. Eng.Trans. 38 33136 (2014).

14. C.D.C. Erbetta, R.J. Alves, J.M. Resende, R.F.S. Freitas, R.G. Sousa. Synthesis and characterization of poly(D,L-Lactide-co-Glycolide) copolymer. J. Biomater. Nanobiotechnol. 3 208-25 (2012).

15. H.R. Kricheldorf, I. Kreiser-Saunders, C. Boettcher. Polylactones: 31. $\mathrm{Sn}$ (II)octoate-Initiated polymerization of L-Lactide: a Mechanistic study. Polymer. 36 (6) 1253-59 (1995). 
JKTI, Vol. 17, No. 2, Desember 2015

16. C. Chuensangjun, C. Pechyen, Sirisansaneeyakul. Degradation behaviors of different blend of polylactic acid buried in soil. Energy Procedia. 34 73-82 (2013).

17. Cai Q, Shi G, Bei J, Wang S. Enzymatic degradation behavior and mechanism of poly(lactide-co-glycolide) foam by trypsin. J. Biomaterials 24 629-38 (2003).

18. T. Renee, MacDonald, P.Stephen, Mc Carthy, R.A. Gross. Enzymatic degradability of poly(lactide): effect of chain stereochemistry and material crystallinity. Macromolecules. 29 735661 (1996). 